INTER NATIONAL MONETARY FUND
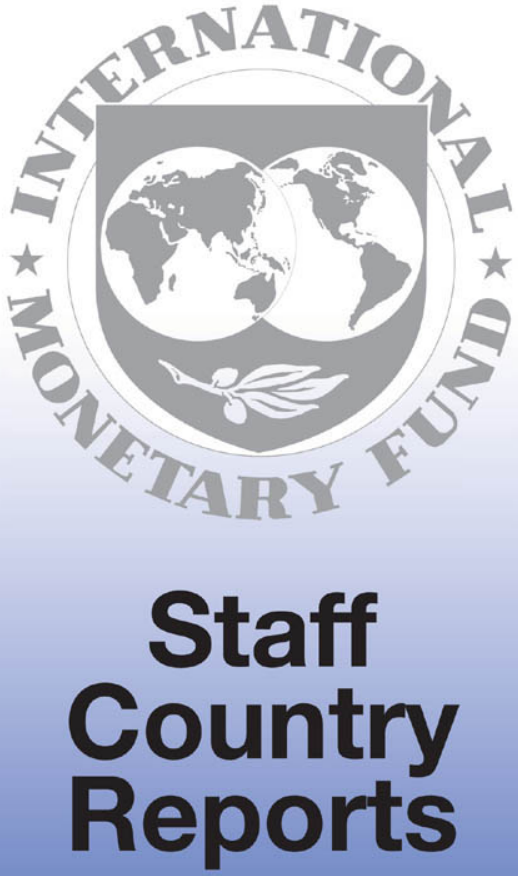


\title{
Monaco: Assessment of the Supervision and Regulation of the Financial Sector Volume I-Review of Financial Sector Regulation and Supervision
}

This review of financial sector regulation and supervision in Monaco in the context of the offshore financial center assessment program contains technical advice and recommendations given by the staff team of the International Monetary Fund in response to the authorities of Monaco's request for technical assistance. It is based on the information available at the time it was completed on May 2003. The staff's detailed assessment of the observance of standards and codes can be found in Volume II. The views expressed in these documents are those of the staff team and do not necessarily reflect the views of the government of Monaco or the Executive Board of the IMF.

The policy of publication of staff reports and other documents by the IMF allows for the deletion of market-sensitive information.

To assist the IMF in evaluating the publication policy, reader comments are invited and may be sent by e-mail to publicationpolicy@imf.org.

Copies of this report are available to the public from

International Monetary Fund $\bullet$ Publication Services

700 19th Street, N.W. • Washington, D.C. 20431

Telephone: (202) $6237430 \bullet$ Telefax: (202) 6237201

E-mail: publications@imf.org • Internet: http://www.imf.org

Price: $\$ 15.00$ a copy

\author{
International Monetary Fund \\ Washington, D.C.
}


This page intentionally left blank

CInternational Monetary Fund. Not for Redistribution 
ASSESSMENT OF THE SUPERVISION AND REGULATION OF THE FINANCIAL SECTOR

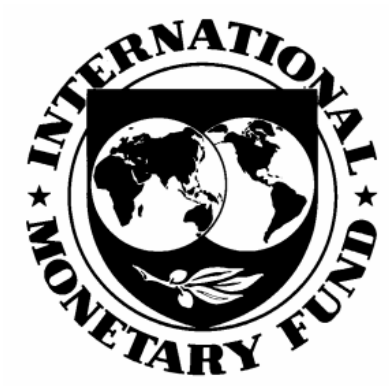

Volume I: Review of Financial Sector Regulation and Supervision

\section{Principality of Monaco}

MAY 2003 
"The contents of this report constitute technical advice and recommendations given by the staff of the International Monetary Fund (IMF) to the authorities of Monaco in response to their request for technical assistance. With the written authorization of the recipient country's authorities, this report (in whole or in part) or summaries thereof may be disclosed to IMF Executive Directors and their staff, and to technical assistance providers and donors outside the IMF. Disclosure of this report (in whole or in part) or summaries thereof to parties outside the IMF other than technical assistance providers and donors shall require the written authorization of the recipient country's authorities and the IMF's Monetary and Financial Systems Department." 


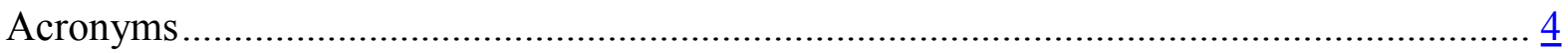

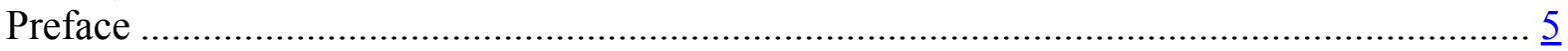

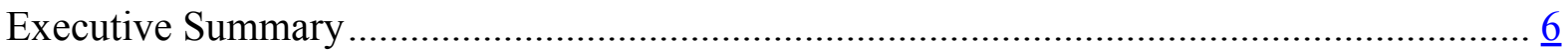

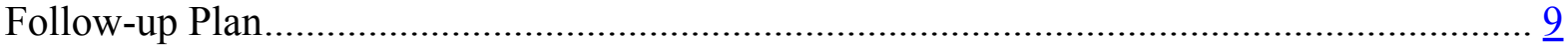

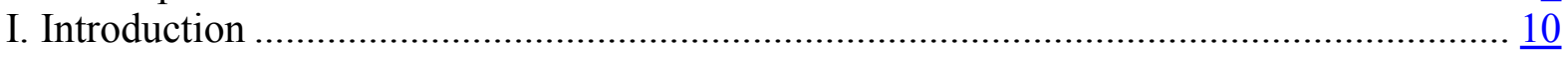

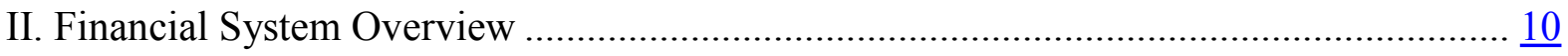

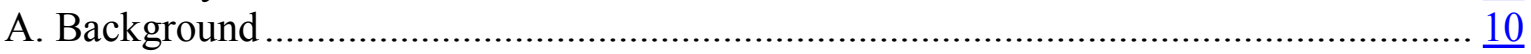

B. Financial Institutions and Markets .................................................................... 13

C. Regulatory Framework, Oversight, and Market Integrity Arrangements ................... $\frac{19}{28}$

III. Observance of Financial System Standards and Codes: Summary Assessments............ $\frac{28}{28}$

A. Basel Core Principles for Effective Banking Supervision ...................................... $\frac{28}{29}$

B. AML/CFT Assessment Based on Fund/Bank Draft Methodology ............................ 29

C. IOSCO Objectives and Principles of Securities Regulation .................................... 36

\section{Text Tables}

1. Key Recommendations and Follow-Up Plan . $\underline{8}$

2. Monaco: Developments in the Financial Sector ......................................................... $\frac{16}{17}$

3. Monaco: Banking Sector ..................................................................................... $\frac{17}{18}$

4. Monaco: Portfolio Management Companies by Age and Activity, 2001......................... $\underline{18}$

5. Monaco: Portfolio Management Companies by Capital and Ownership, 2001 ................18

6. Monaco: Mutual Funds - Market Structure, 2001 .................................................... $\frac{19}{21}$

7. Monaco: Regulatory Structure, 2002 .................................................................

Figure

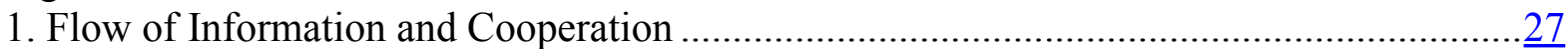




\section{ACRONYMS}

\begin{tabular}{|c|c|}
\hline $\mathrm{AMC}$ & Asset management company \\
\hline AML & anti-money laundering \\
\hline BCP & Basel Core Principle for Effective Banking Supervision \\
\hline CCGP & $\begin{array}{l}\text { Commission de Contrôle de Gestion de Portefeuille et des Activités Boursières } \\
\text { Assimilées (Supervisory Commission for Portfolio Management and Related } \\
\text { Stock Market Activities, Monaco) }\end{array}$ \\
\hline CECEI & $\begin{array}{l}\text { Comité des Etablissements de Crédit et des Entreprises d'Investissement } \\
\text { (Credit Institutions and Investment Firms Committee, France) }\end{array}$ \\
\hline CFT & combating the financing of terrorism \\
\hline Cies & companies \\
\hline $\mathrm{COB}$ & Commission des Opérations des Bourses (Stock Exchange Commission, France) \\
\hline $\mathrm{CRBF}$ & $\begin{array}{l}\text { Comité de la Réglementation Bancaire et Financière (Banking and Financial } \\
\text { Regulatory Committee, France) }\end{array}$ \\
\hline CSOM & $\begin{array}{l}\text { Commission de Surveillance des OPCVM (Supervisory Commission for Mutual } \\
\text { Funds, Monaco) }\end{array}$ \\
\hline CSP & company and trust service provider \\
\hline DEE & $\begin{array}{l}\text { Direction de l'Expansion Economique (Division of Economic Expansion, } \\
\text { Monaco) }\end{array}$ \\
\hline ECB & European Central Bank \\
\hline EU & European Union \\
\hline FATF & Financial Action Task Force \\
\hline FCB & French Commission Bancaire (Banking Commission) \\
\hline FT & financing of terrorism \\
\hline FIU & financial intelligence unit \\
\hline IOSCO & International Organization of Securities Commissions \\
\hline ILR & international letter rogatory \\
\hline MFD* & Monetary and Financial Systems Department \\
\hline ML & money laundering \\
\hline MOU & memorandum of understanding \\
\hline OPCVM & $\begin{array}{l}\text { organismes de placement collectif en valeurs mobilières (undertakings for } \\
\text { collective investments for transferable securities, UCITS) }\end{array}$ \\
\hline SAM & Société Anonyme Monégasque \\
\hline SBM & Société des Bains de Mer \\
\hline SICCFIN & $\begin{array}{l}\text { Service d'Information et de Contrôle sur les Circuits Financiers } \\
\text { (Service for the Information and Supervision of Financial Circuits, Monaco) }\end{array}$ \\
\hline $\mathrm{SO}$ & Sovereign Order \\
\hline STR & suspicious transaction report \\
\hline UCITS & $\begin{array}{l}\text { undertakings for collective investments for transferable securities (investment } \\
\text { funds, mutual funds) }\end{array}$ \\
\hline
\end{tabular}

* The IMF's Monetary and Exchange Affairs Department (MAE) was renamed the Monetary and Financial Systems Department (MFD) as of May 1, 2003. The new name has been used throughout the report. 


\section{PREFACE}

The Offshore Financial Centers Assessment Report for the Principality of Monaco assesses, in particular, the anti-money laundering and combating the financing of terrorism (AML/CFT) regime based on the April 2, 2002 version of the Draft Fund and Bank AML/CFT

Methodology. ${ }^{1}$ It also evaluates the regulation of portfolio management and mutual funds relative to the IOSCO Objectives and Principles of Securities Regulation.

The assessments were carried out during a mission from April 22 to May 3, 2002, whose members included Ms. Mary G. Zephirin (Mission Chief), Ms. Jennifer Elliott (both MFD), Messrs. Louis Forget (Consulting Counsel, LEG), Marcel Maes, and Ronald Ranochak (both consultants), and Ms. Sonia Echeverri (Mission Assistant, MFD). The report was updated in May 2003 to take account of legislation passed, and regulatory measures undertaken, since the mission.

The members of the missions were privileged to meet with the Minister of State, Mr. Patrick Leclercq, Mr. Franck Biancheri, Government Finance and Economic Counselor, Mr. Patrice Davost, Director of Judicial Services, Ms. Sophie Thevenoux, Director of the Budget and Treasury Division, and Ms. Isabelle Rosabrunetto, Assistant to the Director of the Budget and Treasury Division. The mission also met with a number of officials from these institutions and with representatives of various public entities, financial institutions, auditors, and private lawyers.

The members of the mission wish to express their gratitude and deep appreciation to the Monegasque authorities and the staff of all the public institutions which they visited and with whom they worked during their stay for their hospitality, cooperation, and openness in sharing insights and information. The feedback provided by the authorities during all meetings was particularly useful in strengthening the report. Special thanks are in order to

Ms. Sophie Thevenoux for her assistance in organizing the technical activities of the mission and channeling the flow of information and to Ms. Isabelle Rosabrunetto for her very effective handling of logistical support and general assistance to the mission.

\footnotetext{
${ }^{1}$ Prepared by the IMF and the World Bank in consultation with the Financial Action Task Force (FATF) ROSC Working Group, the Basel Committee, the International Association of Insurance Commissioners (IAIS), and the International Organization of Securities Commissioners (IOSCO) and the Egmont Group.
} 


\section{EXECUTIVE SUMMARY}

The Principality of Monaco has in place a comprehensive legal framework, supervisory structure, and practices that support a well regulated financial environment. The authorities have over the past two years adopted a strongly proactive approach to supervision, especially in the AML/CFT area. This emphasis is appropriate to a system largely dominated by internationallyactive private banking and related financial services, the supervision of which benefits from close collaboration with the French supervisory authorities. Monaco's proactive stance, crucial to reducing the potential for reputational risk, could be enhanced by further developing the supervisory architecture through additional formal agreements for information exchange and cooperation, additions to the AML/CFT regime, and some fine-tuning of supervisory arrangements

Monaco's financial system is largely comprised of private banks providing asset management for high-net worth clients who are, in the main, attracted to the jurisdiction by the absence of personal direct taxes on residents, a very secure environment and convenient location. Portfolio management services and mutual funds are also offered by nonbank institutions. Company and trust service providers contribute to Monaco's strategy of attracting wealthy residents by facilitating wealth management services appropriate to the particular circumstances of clients from different jurisdictions. No insurance companies have been established in Monaco, insurance being offered only by the agents or brokers of French insurance companies.

Based on a treaty of 1918 between France and Monaco ${ }^{2}$ and the 1919 Treaty of Versailles, Monaco has close economic and financial relations with France, the specifics of which are determined by several agreements and exchanges of letters. Inter alia, a Convention of 1945 established the principle that French banking regulations would apply in Monaco, and a 1963 Agreement established a customs union between the two, as well as a common legal framework for insurance. These agreements and further exchanges of letters made the banking sector in Monaco subject to French regulations and supervision by the French Commission Bancaire (FCB).

Legally, AML arrangements are a Monegasque responsibility, and portfolio management is subject to Monegasque rather than French regulation. Two commissions supervise securities activities in portfolio management and mutual funds, respectively. At the same time, the FCB, while having no legal responsibility, monitors portfolio management in banks, resulting in some overlap in the oversight of banks' securities activity. Company and trust service providers (CSPs) are licensed and monitored by the Direction de l'Expansion Economique (DEE). SICCFIN, the Monegasque financial intelligence unit (FIU), has an active supervisory role that goes beyond the core functions of an FIU. ${ }^{3}$ It supervises the anti-money laundering regime of all financial institutions, as well as CSPs.

\footnotetext{
${ }^{2}$ A new treaty, replacing the 1918 treaty, was signed in October 2002.

${ }^{3}$ The core functions of an FIU are to collect, analyze, and disseminate financial information and intelligence, consistent with the definition of an FIU set forth by the Egmont Group.
} 
Together with the provisions of the Criminal Code criminalizing money laundering, Law No. 1162 of July 7, 1993, Relating to the Participation of Financial Undertakings in Countering Money Laundering (the AML Law) is the main element of the AML/CFT legal framework in Monaco. The AML Law requires financial institutions to verify the identity of their customers, maintain client and transaction records, have internal controls, and train their staff. In addition, both financial institutions and certain listed professions are required to report suspicious transactions to SICCFIN, which is established pursuant to the AML Law. An amendment to the 1993 AML Law, enacted in July 2002, updates the Law on a number of important points. In particular, it integrates CSPs in the AML/CFT framework and adds a requirement to report transactions related to terrorism financing. The financing of terrorism is criminalized through the Sovereign Order under which Monaco implemented the Convention on the Suppression of the Financing of Terrorism. Freezing of suspect transactions is authorized by law. Confiscation of laundered funds is also authorized and may be obtained by court order.

The assessments carried out reflect the potential risks faced by the jurisdiction and the relative macroeconomic significance of the sectors. Hence, AML-related principles of the Basel Core Principles for Effective Banking Supervision were assessed, and the AML/CFT assessment of non-prudentially regulated institutions covered both CSPs and gaming establishments. In addition, the supervision of portfolio management and mutual funds was assessed relative to the IOSCO Objectives and Principles of Securities Regulation.

Overall, the assessments found that, while the supervisory structure is relatively complex, current arrangements are generally effective but may require strengthening to respond to new challenges and rapid or complex financial developments. The AML/CFT legal and institutional framework is sound and is implemented with increasing efficiency. AML legislation imposes sufficient measures on financial institutions with respect to customer due diligence, record-keeping, suspicious transaction reporting, and internal controls, and SICCFIN is in the process of establishing the procedures and inspections necessary to monitor compliance. Effective sanctions are provided for failure to observe the law. Integrity standards are set out in the laws regulating each industry in the financial sector, and also are implemented through the licensing requirements applicable to all business activities in Monaco.

The system of securities regulation as currently structured is effective within the Monegasque context of careful government planning of commercial activity, which includes a rigorously controlled company registration system, in addition to licensing of securities activity, and explicit limits on permitted securities activity. A recent series of initiatives to allow, for example, for consolidated cross-border supervision in banking and cross-border information sharing among securities regulators has greatly improved Monaco's cross-border cooperation and information-sharing. The resulting system has proven to be effective in practice, but formalizing and clarifying information avenues would optimize the existing arrangements and provide a strong demonstration of continuing progress in strengthening the system. 
Table 1. Key Recommendations and Follow-Up Plan

\begin{tabular}{|c|c|}
\hline Observations & Recommendations \\
\hline \multicolumn{2}{|l|}{ Information Sharing } \\
\hline $\begin{array}{l}\text { Ongoing work, especially with respect to } \\
\text { information-sharing with foreign supervisors, } \\
\text { remains necessary. }\end{array}$ & $\begin{array}{l}\text { The planned MOU between SICCFIN (the FIU) and the French } \\
\text { Commission Bancaire (FCB) should be completed as soon as } \\
\text { possible. } \\
\text { Work on establishing MOUs with foreign supervisory } \\
\text { authorities should be intensified. }\end{array}$ \\
\hline $\begin{array}{l}\text { The Coordination Committee established in } \\
\text { September } 2002 \text { is an important information- } \\
\text { sharing mechanism. However, CSOM is not } \\
\text { represented. }\end{array}$ & $\begin{array}{l}\text { A formal agreement for information exchange should be } \\
\text { developed between SICCFIN and CSOM. }\end{array}$ \\
\hline $\begin{array}{l}\text { Information sharing between the Supervisory } \\
\text { Commission for Portfolio Management } \\
\text { (CCGP) and the FCB depends on the dual } \\
\text { roles of the Director of Budget and Treasury. }\end{array}$ & $\begin{array}{l}\text { To provide, in the medium term, for possible changes in } \\
\text { industry structure, to strengthen the cooperative base and } \\
\text { enhance regulatory reputation; arrangements for information } \\
\text { exchange between these parties should be formalized. }\end{array}$ \\
\hline $\begin{array}{l}\text { There is legal provision for information } \\
\text { sharing between the CCGP and foreign } \\
\text { supervisory authorities provided a formal } \\
\text { arrangement is in place. Similar provisions } \\
\text { were not made for the mutual funds } \\
\text { supervisory commission. }\end{array}$ & $\begin{array}{l}\text { The mutual funds law should be amended to allow for } \\
\text { information sharing with foreign supervisory authorities. }\end{array}$ \\
\hline \multicolumn{2}{|l|}{ AML/CFT } \\
\hline $\begin{array}{l}\text { Terrorism financing is being brought into } \\
\text { AML framework, but is not a predicate } \\
\text { offence for money-laundering. }\end{array}$ & $\begin{array}{l}\text { The financing of terrorism should be made a predicate crime for } \\
\text { money laundering, and the list of predicate offenses should be } \\
\text { reviewed to ensure that all serious offenses are included. }\end{array}$ \\
\hline $\begin{array}{l}\text { Customer due diligence arrangements are in } \\
\text { place and observed but could benefit from } \\
\text { some enhancement. }\end{array}$ & $\begin{array}{l}\text { Increased due diligence for higher risk customers, especially } \\
\text { politically exposed persons (PEPs), their families, and } \\
\text { associates. }\end{array}$ \\
\hline $\begin{array}{l}\text { SICCFIN's supervisory role is expanding and } \\
\text { the AML/CFT workload is very heavy. }\end{array}$ & $\begin{array}{l}\text { A comprehensive review of SICCFIN's ongoing work should be } \\
\text { undertaken, preferably no later than in the second half of } 2003 \text {. }\end{array}$ \\
\hline $\begin{array}{l}\text { Legislation on confiscation of assets does not } \\
\text { include confiscation of "instrumentalities" (i.e. } \\
\text { assets used in the commission of a crime), and } \\
\text { does not provide for the confiscation of assets } \\
\text { of equivalent value. }\end{array}$ & $\begin{array}{l}\text { The legislation on confiscation should be modified to provide } \\
\text { for confiscation on instrumentalities of crime and for } \\
\text { confiscation of assets of equivalent value. }\end{array}$ \\
\hline $\begin{array}{l}\text { DEE is responsible for general CSP oversight } \\
\text { but SICCFIN assumed responsibility for } \\
\text { AML/CFT in CSPs in the July } 2002 \mathrm{AML} \\
\text { Law. }\end{array}$ & $\begin{array}{l}\text { Ensure that the new arrangements for dividing supervisory } \\
\text { responsibilities between DEE and SICCFIN are well executed. }\end{array}$ \\
\hline
\end{tabular}




\begin{tabular}{|l|l|}
\hline \multicolumn{1}{|c|}{ Observations } & \multicolumn{1}{c|}{\begin{tabular}{c}
\multicolumn{1}{c|}{ Recommendations } \\
Mortfolio Management
\end{tabular}} \\
\hline $\begin{array}{l}\text { The legal framework is comprehensive and is } \\
\text { supported by a system of reporting and } \\
\text { inspections. The Supervisory Commissions } \\
\text { bring important skills to the regulatory } \\
\text { structure. }\end{array}$ & $\begin{array}{l}\text { To enhance soundness of regulation and establish a system } \\
\text { compatible with international practices, in the short term, } \\
\text { serious consideration should be given to a merger of the two } \\
\text { Commissions and, in the medium term, greater independence of } \\
\text { the regulator. }\end{array}$ \\
& $\begin{array}{l}\text { Additional attention to transparency and accountability, and the } \\
\text { development of conflicts of interest policies would enhance the } \\
\text { quality of the regulatory structure. }\end{array}$ \\
\hline
\end{tabular}

\section{FOLLOW-UP PLAN}

- $\quad$ Customer due diligence: SICCFIN plans to issue a new set of guidelines covering increased due diligence for higher risk customers and politically exposed persons. ${ }^{4}$

- $\quad$ Organization of the regulation of mutual funds and portfolio management: The Monegasque authorities acknowledge the complexity of the structures now in effect to monitor the financial sector in comparison to the size of this sector. The merger of the two commissions, CSOM and CCGP, is already a step that the authorities plan to take in the near future. However, considering the general evolution of the matter worldwide (FSA in Great Britain, merger of COB and CMF in France), this should only be considered a first step. A major evolution would be to create a legal entity that would be entrusted with all the missions of a financial supervisor. SICCFIN would keep its role of FIU, reporting to the judicial authorities. The role of the Finance and Economic Department and Direction du Budget et du Trésor would mainly consist of drafting the legislation submitted to Parliament. This evolution could be considered only after the current organisation of surveillance has been examined and evaluated in order that the new structure give priority to addressing identified weaknesses.

\footnotetext{
${ }^{4}$ The authorities noted (see paragraph 16, Volume II) that: the Swiss supervisor recently asked all Swiss banks present in the center to carry out a thorough review of the application of Swiss standards concerning PEP (politically exposed persons). During 2001 and 2002, 11 Swiss subsidiaries/branches in Monaco were inspected by their group external auditors. The reports were made available to the local supervisor and resulted in the confirmation of the effectiveness of the procedures used.
} 


\section{INTRODUCTION}

1. At the invitation of the Government of the Principality of Monaco, a Module II offshore financial center (OFC) assessment of financial regulation and supervision in Monaco was carried out from April 22 to May 3, 2002, within the framework of the OFC Assessment Program, approved by the Executive Board of the Fund in July 2000. It was updated in May 2002. In line with the objectives of that initiative, the assessment focused on the sectors of most economic and financial significance to the jurisdiction, taking account of the potential vulnerabilities most likely to affect financial services offered by the jurisdiction.

2. The financial sector's wealth management services are a crucial component of Monaco's economic strategy. Minimizing reputational risk and maintaining the integrity of the system are therefore important supervisory goals. The banking system is often the sector most vulnerable to both these concerns. However, banking activity in Monaco is regulated and supervised by the French supervisory system which was assessed in 2000; hence, the $\mathrm{BCP}$ assessment focused on the AML principles for which the Monegasque authorities are responsible. The AML/CFT assessment was made under the Fund/Bank April 2002 Methodology and covered banks, security intermediaries, company and trusts service providers, and gaming establishments. Inclusion of the latter was dictated by the macroeconomic implications of the reputational risk to which the jurisdiction could be exposed by the gaming sector, especially in view of the identification made between casino and jurisdiction. The regulation and oversight of portfolio management and mutual funds were also assessed.

3. The assessment also explicitly examined two areas of particular importance in the OFC context: company and trust service providers and cross-border cooperation and information sharing. A good understanding of CSPs' operations would support the financial sector's wealth management focus, and sound cross-border information sharing arrangements would both support the jurisdiction's reputation and assist other supervisors in maintaining robust systems.

4. In view of the unique features of the Monegasque supervisory system, the overview of the financial system begins by providing a general description of the key political and economic features of the country.

\section{FinANCiAL SySTEM OVERVIEW}

\section{A. Background}

5. The Principality of Monaco, with a total area of about two square miles, had a resident population in 2000 of about 32,000 persons, some 6,000 of whom are Monegasque nationals; 39 percent and 25 percent of other residents are French and Italian nationals, respectively. Remaining residents hold a variety of other nationalities. 


\section{Government}

6. The Principality of Monaco is a sovereign state whose government is defined by the 1962 Constitution as a hereditary constitutional monarchy.

7. Executive power is exercised on the authority of the Prince by a Minister of State who represents the Prince and is assisted by a Council of Government. The three members of the Council head specialized departments of the administration: (i) finance and the economy; (ii) public works, social affairs; (iii) interior affairs, including health, the police, and general administration. The Minister and the Councillors are responsible to the Prince for the administration of the Principality. Legislative power is exercised by the Prince, who initiates legislation, and by a 24-member elected National Council. ${ }^{5}$

8. Under the 1962 Constitution, judicial power belongs to the Prince who delegates it to the courts and tribunals. The Constitution states that "The independence of the judges is guaranteed." Monegasque and French magistrates sit on the courts, the French having the majority of the seats under a 1930 agreement.

\section{Economic relations with France}

9. Monaco's relationship with France is based on a treaty of 1918 in which, in exchange for the undertaking by France to guarantee the sovereignty and territorial integrity of Monaco, Monaco commits to exercise its sovereignty in conformity with the interests of France, and on the 1919 Treaty of Versailles. The 1918 treaty was updated and replaced by a treaty signed on October 24, 2002, to provide for greater reciprocity of treatment between the two states. An agreement of 1930 allows for the employment of French civil servants in security, public order, and foreign relations. Under that agreement, the Minister of State is a French national chosen by the Prince from a list of three names proposed by France. Several bilateral agreements signed in May 1963 deal with Monegasque-French arrangements in customs, pharmaceuticals, insurance, post, and telecommunications.

10. By the May 18, 1963 Customs Agreement, Monaco and France formed a customs union under which French customs laws and regulations are applicable in the Principality. The fiscal arrangements between Monaco and France are determined by a treaty of 1950 aimed at avoiding double taxation, and by a 1963 treaty by which French citizens resident in Monaco remain subject to French income tax; a profit tax of $331 / 3$ percent was imposed on

\footnotetext{
${ }^{5}$ The Constitution was changed in April 2002 to increase the number of Council members from 18 to 24 . Currently, and until the next elections, there are actually 18 Councillors.
} 
industrial and commercial business which has at least 25 percent of its turnover from operations outside of Monaco, and value-added tax (VAT) was put in place in Monaco on the same basis, and with the same rules, as in France.

\section{Financial relations with France}

11. The financial regulatory and supervisory arrangements between Monaco and France are based on an April 14, 1945 agreement and amendments adopted by exchanges of letters between the two countries in 1963, 1987, and 2001. The 1945 agreement applied then current and future French laws and regulations for banking to Monaco.

12. The May 18, 1963 exchange of letters established the scope of and the procedures for implementation of the application of French banking law. The November 27, 1987 exchange specified that the regulations concerning banks made by the French Comite de la Règlementation Bancaire (CRBF), with the participation of a Monegasque representative, should apply in Monaco; that the French Commission Bancaire (FCB) should be responsible for supervision, including onsite inspection, of credit (i.e., banking) institutions in Monaco; and that the Comité des Etablissements de Crédit et des Entreprises d'Investissement (CECEI) of France would license credit institutions. Under these arrangements, the French Banking Act of 1984 applies to credit institutions in Monaco. However, legislative provisions concerning, for example, criminal matters, which are specific to France and do not specifically concern credit institutions, are not applicable in Monaco which has its own laws in these areas. ${ }^{6}$ As a result, Monegasque credit institutions are subject to Monegasque, not French, AML/CFT legislation and rules.

13. Similar common arrangements do not exist for securities-related activities. Law No. 1.130 of January $8,1990,{ }^{7}$ and the related ministerial and sovereign orders set out conditions for the operation of mutual funds and their supervision. Previous to the French 1996 Financial Activities Modernization Act, portfolio management activity by banks was considered part of banking and supervised by the French. The Modernization Act distinguished between banking and securities, ending the FCB's supervisory responsibility for bank securities business. The Monegasque Law No. $1.194^{8}$ legislated conditions for portfolio management, related activities and their regulation in banks and other institutions. Securities and regulation are thus the responsibility of the Monegasque government. In

\footnotetext{
${ }^{6}$ In addition, some of the provisions of the 1984 Act referring to French criminal or company law are only applicable in Monaco with reference to Monegasque law.

${ }^{7}$ Amended in 2000.

${ }^{8}$ Amended in 2001 .
} 
practice, personnel of the French COB are relied on to carry out inspections of mutual fund companies on behalf of the mutual fund supervisory commission, CSOM (see Section C below).

14. Following a 1925 agreement, the French franc became legal tender in Monaco. Monaco has now adopted the Euro, although it is not a member of the European Union, following negotiations with France which had been delegated the requisite authority by the EU Council of Ministers (see Monetary Convention published with Sovereign Order (SO) 15.185 of January 14, 2002). Monegasque institutions must observe the reserve requirements and statistical reporting obligations of the European Central Bank, ECB, (SO 13.889 of February 18, 1999). Monegasque credit institutions are also subject, under this agreement, to the imposition of sanctions for failure to comply with ECB requirements. At the same time, credit institutions participate in the payments system of the Euro area on the same terms as French credit institutions.

\section{Economy}

15. In 2000, total private sector turnover was estimated at €9.2 billion (Monaco’s GDP is not estimated separately from that of France), 38 percent of which was generated in wholesale and retail distribution (29 percent of distribution being hotel and restaurant retail), and 21 percent in banking and finance, the second largest sector by this measure. Industry, at 8 percent (49 percent in pharmaceuticals and cosmetics) of the total, is also relatively important. Tourism, although not distinguished in these measures (hotel and restaurant is only 3 percent of total turnover), is an important source of business activity, with arrivals of over 300 thousand in 2000, most visitors coming from Italy, France, the U.S.A., and the U.K. Business tourism is growing, encouraged by conference facilities: in the second half of the 1990 s, business visitors averaged about one third of bed-nights, as compared to 20-25 percent in the early 1990 s.

16. There are no direct taxes on property, capital or the income of residents, with the exception of French nationals who became resident after 1957, whose total income is subject to French income tax. As mentioned, there is also a profit tax of 33 percent on industrial and commercial business which has at least 25 percent of its turnover from operations outside Monaco.

\section{B. Financial Institutions and Markets}

17. The Monegasque financial system is dominated by private banking, asset management for high-net worth clients being, in general, the predominant service provided. In addition to the portfolio management handled by the banks themselves, the most significant areas of financial activity are portfolio management by independent companies, and the marketing of mutual funds (Tables 2 and 3 ). 
18. Private banking and related activities have become a mainstay of the financial system because of the diverse attractions of the Monegasque environment (historical circumstances, the fiscal regime, geography), to individuals, and the response of European wealth managers to the growing market. Both banks and professional services have moved there in the wake of their clients and in anticipation of expanding their market share. Monaco's absence of direct tax on the income of residents has traditionally been the primary drawing point, and the strict duty of confidentiality observed by financial institutions has also been attractive. The banks argue, however, that the high level of personal security and safety fostered by the government, the pleasant life style, and convenient location (with good telecommunications) near clients' countries of citizenship are increasing in importance relative to the tax advantages.

19. The banking system's balance (and off-balance) sheet structure reflects this clientele. Managed funds are over 50 percent larger than deposits. Credit is a fraction of deposits; hence, the Monegasque banking system is a net interbank creditor (Table 3). The growth in the sector, illustrated by both deposited funds and the number of employees, which grew by a third in the four years to 2000 (Table 3), is attributed to increasing wealth, especially in the U.K., Italy, and Spain, countries whose entrepreneurs may choose to take early retirement in Monaco.

20. Managed portfolios at both banks and the non-bank management companies (Table 2) take two forms: discretionary and advisory arrangements. In the first case, the bank or company manages the funds without the need for client decisions on each transaction. Customers specify their risk tolerance, desired investment profile, and reference currency in a contract with the firm which defines the latter's mandate. In an advisory arrangement, the client makes the investment decisions on the advice of the banker. There are 24 nonbank management companies, some of which offer quite limited services (Tables 4 and 5), but banks do most of the business (Table 2).

21. Mutual funds (Tables 2 and 6) are both dedicated and general mutual funds, the former being funds essentially designed for a single holder. The Monegasque mutual funds, with different risk profiles aimed at a range of customers, help the institutions market their services among retail customers. Investment of these funds is often sub-delegated to specialized portfolio managers, either within the group or in third party institutions. Local staff and physical presence is important for relationship building and maintenance.

22. Company service providers contribute to Monaco's strategy of attracting wealthy clients as new residents. The need for competent wealth management, tax and estate planning advice is important to this market, and the 40 company and trust service providers licensed in Monaco (Table 2) facilitate the entry of many of these prospective residents. This is particularly so for foreigners relocating from common law jurisdictions. Most hold assets in corporate form and have wills and trusts to distribute their wealth in accord with home country law. In addition to providing appropriate wealth management and tax planning 
strategies, company and trust service providers provide management services that ensure compliance with Monegasque law as well as preserve status under home country law, an important consideration in estate planning.

23. Since Monaco is a civil law jurisdiction, it has made a particular accommodation to facilitate the residence of clients from common law jurisdictions by authorizing a special category of trust under Law No. 214 of 1936 on the constitution of trusts. Trusts formed under Law No. 214 are unique to Monaco with in excess of 95 percent being testamentary trusts. The trust is essentially a will substitute and comes into force only upon death of the person forming the trust. The single purpose of Law No. 214 trusts is to permit persons (often from English-speaking jurisdictions) resident in Monaco to retain common law as the governing law for their wills, thus avoiding the forced heir-ship requirement under local civil code.

24. No insurance companies are incorporated in Monaco. There are 49 insurance brokers and agents, representing or offering the products of some 150 companies established in France. Insurance companies are among the financial institutions covered by the May 18, 1963 treaty. Like other economic entities, brokers and agents must be authorized by the Direction de l'Expansion Economique (DEE). 
Table 2. Monaco: Developments in the Financial Sector

\begin{tabular}{|c|c|c|c|c|}
\hline \multirow[b]{2}{*}{ Type of Institution } & \multicolumn{4}{|c|}{ Year ending December 31} \\
\hline & 1998 & 1999 & 2000 & 2001 \\
\hline & \multicolumn{4}{|c|}{ (Number) } \\
\hline \multicolumn{5}{|l|}{ Credit Institutions } \\
\hline Number & 49 & 49 & 49 & 51 \\
\hline Sociétés Anonymes Monégasque & 20 & 20 & 21 & 22 \\
\hline Branches of foreign banks & 3 & 4 & 5 & 7 \\
\hline Branches of French banks & 19 & 18 & 16 & 15 \\
\hline Municipal credit company & 1 & 1 & 1 & 1 \\
\hline Monégasque finance companies & 4 & 4 & 4 & 4 \\
\hline \multirow[t]{2}{*}{ Branches of French finance companies } & 2 & 2 & 2 & 2 \\
\hline & \multicolumn{4}{|c|}{ (million Euro) } \\
\hline \multicolumn{5}{|l|}{ Banks } \\
\hline Total assets (balance sheet) & 39,580 & 50,531 & 56,174 & 58,505 \\
\hline Assets under management & 20,629 & 29,702 & 32,129 & 32,602 \\
\hline Deposits & 15,843 & 16,524 & 18,549 & 20,239 \\
\hline Loans & $\ldots$ & $\ldots$ & 2,955 & 2,863 \\
\hline Return on assets (average) & 0.45 & 0.60 & 0.82 & \\
\hline Return on equity (average) & 13.8 & 18.2 & 26.1 & $\ldots$ \\
\hline \multicolumn{5}{|l|}{ Portfolio Management Companies } \\
\hline Number & 18 & 23 & 28 & 24 \\
\hline Assets under management (million euro) & $\ldots$ & $\ldots$ & 2,944 & 5,015 \\
\hline \multicolumn{5}{|l|}{ Investment Funds } \\
\hline Number & 49 & 52 & 52 & 60 \\
\hline Total assets (million euro) & 3,297 & 4,313 & 4,713 & 5,213 \\
\hline Mutual funds & 1,318 & 2,076 & 2,270 & 2,701 \\
\hline Dedicated mutual funds & 1,979 & 2,237 & 2,443 & 2,512 \\
\hline \multicolumn{5}{|l|}{ Insurance 1/ } \\
\hline No. of broker licenses & & & & 39 \\
\hline No. of agent licenses & & & & 23 \\
\hline Total agent/broker entities $2 /$ & & & & 49 \\
\hline \multicolumn{5}{|l|}{$\begin{array}{l}\text { Company and Trust Service Providers (CSPs) by } \\
\text { corporate structure } 2 /\end{array}$} \\
\hline Sociétés Anonymes Monégasques (SAM) / & & & & 25 \\
\hline in general business & & & & 19 \\
\hline managing single-family wealth & & & & 6 \\
\hline Sociétés en nom collectif (SNC) & & & & 8 \\
\hline Sociétés en commandite simple (SCS) & & & & 2 \\
\hline Individuals & & & & 5 \\
\hline \multicolumn{5}{|l|}{ Memorandum items: } \\
\hline & & (Numbers & & \\
\hline Sociétés Anonymes Monégasques (SAM) 3/ & 1222 & 1217 & 1180 & 1173 \\
\hline Sociétés en nom collectif (SNC) & 94 & 102 & 100 & 98 \\
\hline Sociétés en commandite simple (SCS) & 432 & 520 & 553 & 556 \\
\hline Sociétés en commandite par actions (SCA) & 4 & 4 & 4 & 4 \\
\hline
\end{tabular}

Sources: Direction du Budget et du Trésor, Monaco

Notes: ... not available

$1 /$ Data is at May 2002.

2/ Some general agents are also brokers for other insurance companies. The agents and brokers represent 44 life companies, 101 property and casualty, and 1 private retirement fund.

3/ SAM is a limited liability company; SNC is a general partnership; SCS is a limited partnership; SCA is a limited partnership with shares, but none have been created since 1976.

4/ Includes some of the financial companies listed above. 
Table 3. Monaco: Banking Sector

\begin{tabular}{|c|c|c|c|c|}
\hline & 1998 & 1999 & 2000 & 2001 \\
\hline & \multicolumn{4}{|c|}{ (In millions of euro, unless otherwise specified) } \\
\hline \multicolumn{5}{|l|}{ Deposits } \\
\hline By holder & 15,815 & 16,671 & 18,546 & 20,249 \\
\hline Resident & 5,502 & 6,114 & 6,682 & 6,894 \\
\hline Of which Individuals & 3,737 & 4,087 & 4,615 & 4,873 \\
\hline Business & 1,765 & 1,417 & 1,547 & 2,021 \\
\hline Non-resident & 10,313 & 10.557 & 11,864 & 13,355 \\
\hline By type & 15,815 & 16,671 & 18,546 & 20,239 \\
\hline Sight & 3,404 & 3,634 & 3,632 & 4,080 \\
\hline Savings & 12,309 & 12,847 & 14,724 & 16,044 \\
\hline TCN 1/ & 102 & 190 & 190 & 115 \\
\hline \multirow[t]{2}{*}{ FF per Euro } & 6.55966 & 6.55957 & 6.55957 & 6.55957 \\
\hline & \multicolumn{4}{|c|}{ (Percentage) } \\
\hline \multicolumn{5}{|l|}{ By currency } \\
\hline euro & & 62 & 58 & \\
\hline US dollars & & 27 & 30 & 25 \\
\hline sterling & & 7 & 6 & \\
\hline other & & 4 & 6 & \\
\hline Employment & 1,755 & $\ldots$ & 2,128 & \\
\hline \multicolumn{5}{|l|}{ Interbank Activity } \\
\hline \multirow{2}{*}{\multicolumn{5}{|c|}{$\begin{array}{l}\text { By nationality of bank } \\
\text { Loans }\end{array}$}} \\
\hline & & & & \\
\hline Monegasque & 12,325 & 12,167 & 14,765 & 18,022 \\
\hline French & 6,261 & 6,040 & 6,401 & 3.993 \\
\hline Other & 3,404 & 2,659 & 1,318 & 621 \\
\hline \multicolumn{5}{|l|}{ Borrowing } \\
\hline Monegasque & 3,944 & 3,741 & 3,674 & 5,369 \\
\hline French & 3,066 & 3,242 & 3,729 & 1,299 \\
\hline Other & 1,550 & 758 & 520 & 141 \\
\hline \multicolumn{5}{|l|}{ Net position, all banks } \\
\hline Monegasque & 8,381 & 8,426 & 11,091 & 12,654 \\
\hline French & 3,195 & 2,798 & 2,672 & 2,694 \\
\hline Other & 1.854 & 1,901 & 798 & 481 \\
\hline Credit & 1,933 & 2,763 & 2,953 & 2,859 \\
\hline \multicolumn{5}{|c|}{ By residence of and type of borrower } \\
\hline Residents & 1,033 & 1.219 & 1,291 & 1,264 \\
\hline Of which Individuals & 429 & 568 & 526 & 569 \\
\hline Business & 596 & 635 & 746 & 695 \\
\hline Non-resident & 900 & 1,544 & 1,662 & 1,595 \\
\hline \multicolumn{5}{|c|}{ Managed portfolios, non-financial client } \\
\hline Total & 20,766 & 29.728 & 32,172 & 32,600 \\
\hline \multicolumn{5}{|l|}{ Composition } \\
\hline Of which shares & 4,280 & 7.797 & 9,060 & 7,800 \\
\hline bonds & 9,819 & 12,144 & 12,075 & 13,669 \\
\hline mutual funds & 6,301 & 9,374 & 10.684 & 10,505 \\
\hline
\end{tabular}

Source: Banque de France, Nice

Notes: 1 TCN = titres de créances négociables 
Table 4. Monaco: Portfolio Management Companies by Age and Activity, 2001

\begin{tabular}{rccccc}
\hline \multicolumn{1}{c}{$\begin{array}{c}\text { Year of } \\
\text { License }\end{array}$} & PM, TO, A & To & TO, A & PM,A & Total \\
& & & & & \\
\hline 1997 & 1 & & 1 & 1 & 1 \\
1998 & 6 & 1 & 1 & 1 & 6 \\
1999 & 3 & & & & 5 \\
2000 & 5 & & & & 3 \\
2001 & 3 & 2 & 2 & 2 & 24 \\
\hline
\end{tabular}

Notes: $1 / \mathrm{PM}=$ portfolio management, term instruments for third parties $\mathrm{TO}=$ transmission of orders to financial markets $\mathrm{A}=$ advice and assistance in above.

Table 5. Monaco: Portfolio Management Companies by Capital and Ownership, 2001

\begin{tabular}{|c|c|c|c|c|c|c|c|c|}
\hline \multirow{2}{*}{$\begin{array}{c}\text { Capital } \\
\text { (000 euro) }\end{array}$} & \multicolumn{8}{|c|}{ Shareholder } \\
\hline & Switzerland & Monaco & USA & France & UK & Individuals & Luxembourg & Total \\
\hline $300-499$ & 2 & & 1 & 1 & 1 & 4 & 1 & 10 \\
\hline $500-699$ & 4 & 1 & & & & & 2 & 7 \\
\hline $700-999$ & 1 & 1 & & & & 1 & & 3 \\
\hline $1000-1199$ & & & & & & & & 0 \\
\hline 1500 & & 1 & & & & & & 1 \\
\hline 2500 & & & & 1 & & & & 1 \\
\hline NA & & 1 & & & 1 & & & 2 \\
\hline Total & 7 & 4 & 1 & 2 & 2 & 5 & 3 & 24 \\
\hline
\end{tabular}

Note: NA - branch or not yet incorporated 
Table 6. Monaco: Mutual Funds - Market Structure, 2001

\begin{tabular}{|c|c|c|c|c|}
\hline \multicolumn{2}{|c|}{ Custodian Bank } & \multirow{3}{*}{$\begin{array}{c}\text { Size of } \\
\text { Funds } \\
2001\end{array}$} & \multirow{2}{*}{\multicolumn{2}{|c|}{ Market Share }} \\
\hline \multirow[t]{3}{*}{ Incorporation } & \multirow[t]{2}{*}{ Parent Co. } & & & \\
\hline & & & 2001 & 2000 \\
\hline & & ( mn Euro) & \multicolumn{2}{|c|}{ (percentage) } \\
\hline Monaco & Switzerland & 1,705 & 32.7 & 36.8 \\
\hline Monaco & Monaco & 1,313 & 25.2 & 20.4 \\
\hline Monaco & France & 1,722 & 33.0 & 34.1 \\
\hline Monaco & France/Italy & 76 & 1.5 & 0.9 \\
\hline \multirow[t]{2}{*}{ Monaco } & UK & 397 & 7.6 & 7.8 \\
\hline & Total & 5,213 & 100.0 & 100.0 \\
\hline
\end{tabular}

Source: Direction du Budget et du Trésor, Monaco

\section{Regulatory Framework, Oversight, and Market Integrity Arrangements}

25. Monaco, with important French participation, has in place a supervisory and regulatory framework adapted to manage most risks confronting its financial sector. In addition to two commissions appointed to advise the Minister of State on regulatory matters in the securities business, company service providers are overseen by the Department of Economic Expansion, and AML-CFT is supervised by the Monegasque FIU, the Service d'Information et de Contrôle sur les Circuits Financiers (SICCFIN). Table 7 summarizes the supervisory structure and its staffing.

26. The Monegasque banking system, which dominates the financial sector, is subject to the same regulatory and supervisory arrangements as the French system, with the exception of AML/CFT arrangements. Legislation in force in France and regulations for credit institutions, including capital requirements, operational standards, prudential ratios and deposit insurance, are laid down by the French CRBF, in whose Monaco-related meetings participates a representative of the Monegasque government. However, portfolio management is subject to Monegasque, not French, regulations. Licensing of Monegasque credit institutions is carried out by the French CECEI, following verification that the Monegasque authorities are in agreement with establishment of the institution. The FCB is responsible for supervising Monegasque credit institutions in areas outside of AML and portfolio management; although, it must consider these in its overall prudential supervision of a bank's activities. Its disciplinary measures are applicable in Monaco, exercised by the Monegasque authorities. Meetings of both the CECEI and FCB dealing with Monegasque matters are attended by a representative of the Monegasque government. The conclusions of the 2000 IMF-led assessment of FCB's compliance with the Basel Core Principles for Effective Banking Supervision are broadly applicable to the supervision of the Monegasque banking system. Apart from AML rules, the main differences between French and 
Monegasque supervisory arrangements are the arrangements for cooperation and information exchange with foreign supervisors and competent authorities.

27. All companies operating a business in the Principality must be registered and as part of this registration must have all their activities approved. The Monegasque system, therefore, does not permit what is not specifically provided for, and securities legislation permits only two kinds of activity: the establishment, operation and distribution of mutual funds. and operation of investment firms which are limited to portfolio management, investment advice, and transmission of orders.

28. Authority to regulate securities activity in Monaco is vested in the Minister of State as the administrator of all laws in Monaco; two consultative commissions advise him. The mutual fund law (Law No. 1.130 and SO No. 9.867 of 1990) appoints a supervisory commission to advise the minister in matters related to mutual fund regulation (the Commission de Surveillance des OPCVM or Supervisory Commission for Mutual Funds) and the portfolio management law, Law No. 1.194 of 1997, appoints a separate commission to advise the minister in matters related to market intermediaries (the Commission de Contrôle de Gestion de Portefeuille et des Activités Boursières Assimilées or Supervisory Commission for Portfolio Management and Related Stock Market Activities).

29. The supervisory commissions, which currently share a Chairman, act in an advisory capacity and make recommendations to the Minister of State but do not have binding authority in any matter. Day-to-day operations are handled by staff of the Department of Finance and Economics. As a result of these arrangements, portfolio management activities in banks are subject to some supervisory overlap. Inspections of mutual fund companies are undertaken by staff of the French Commission des Opérations des Bourses (COB) pursuant to a 1992 agreement between the Ministry of State and the COB. Enforcement activities are undertaken by the public prosecutor. Although the structure appears to be somewhat fragmented in description, the very small number of people involved and the concentrated nature of government in Monaco mean that, in practice, the system is well coordinated and functions smoothly.

30. SICCFIN is the AML/CFT supervisory body for the financial sector in Monaco. SICCFIN was established by SO No. 11.246 of April 12, 1994 (amended by SO No. 15.452 of August 8, 2002), pursuant to Law No. 1.162 of July 7, 1993 relating to the participation of financial undertakings in countering money laundering (the AML Law). ${ }^{9}$ SICCFIN's mandate is to gather, seek, process, and circulate information on financial circuits used to launder money (Article 2 of SO No. 11.246). The AML Law also provides that SICCFIN is responsible for monitoring the application of the AML Law and the measures taken in its

\footnotetext{
${ }^{9}$ Law No. 1.162 was amended by Law No. 1.253 of July 12, 2002. Unless the context requires a different interpretation, references in this report to the AML Law are to the law as amended.
} 
application (Article 26 of the AML Law). On the basis of these provisions, SICCFIN carries out the following activities: (i) AML supervision of reporting institutions, including onsite inspections; (ii) awareness-raising activities with industry associations of reporting entities, such as the Association Monégasque des Banques; (iii) staff training; (iv) participation in local and international meetings; (vi) receiving and analyzing reports of suspicious transactions; and (vii) cooperation with other FIUs. As a result, SICCFIN has a much wider mandate than is usual for FIUs.

31. The AML Law makes two sets of entities subject to its provisions. Financial institutions are subject to all provisions of the law regarding customer identification, special scrutiny for certain transactions, record keeping, vigilance and internal controls and suspicious transaction reporting. These financial institutions (listed in Article 1 of the law) include banks, insurance companies, portfolio management firms, bureaux de change, and company service providers. A wide range of other professionals (listed in SO No. 14.466 of April 22, 2000, issued pursuant to Article 2 of the AML Law), are made subject to suspicious transaction reporting requirements.

Table 7. Monaco: Regulatory Structure, 2002

\begin{tabular}{|c|c|c|c|}
\hline Financial Institution & $\begin{array}{c}\text { Supervisory } \\
\text { Department or Body }\end{array}$ & Number of Staff & $\begin{array}{c}\text { Number of } \\
\text { Specialized staff }\end{array}$ \\
\hline Credit institutions & $\begin{array}{l}\text { FCB } \\
\text { SICCFIN - AML/CFT } \\
\text { DBT }\end{array}$ & $\begin{array}{l}9 \\
6\end{array}$ & $\begin{array}{l}8 \\
4\end{array}$ \\
\hline $\begin{array}{l}\text { Insurance } \\
\text { companies } \\
\text { brokers } \\
\text { agents }\end{array}$ & $\begin{array}{l}\text { not applicable } \\
\text { SICCFIN - AML/CFT } \\
\text { SICCFIN - AML/CFT } \\
\text { DEE - general }\end{array}$ & $\begin{array}{r}9 \\
9 \\
20\end{array}$ & $\begin{array}{r}8 \\
8 \\
12\end{array}$ \\
\hline $\begin{array}{l}\text { Portfolio management } \\
\text { banks }\end{array}$ & $\begin{array}{l}\text { CCGP, FCB; DF } \\
\text { SICCFIN - AML/CFT }\end{array}$ & $\begin{array}{r}\text { CCGP - } 7 \text { members } \\
\text { DF - } 9\end{array}$ & $\begin{array}{r}\text { CCGP - } 7 \text { members } \\
\text { DF - } 4\end{array}$ \\
\hline other & $\begin{array}{l}\text { CCGP, DF } \\
\text { SICCFIN - AML/CFT }\end{array}$ & as above & as above \\
\hline Mutual Funds & $\begin{array}{l}\text { CSOM } \\
\text { SICCFIN - AML/CFT }\end{array}$ & CSOM - 6 members & CSOM - 6 members \\
\hline CSPs & DEE, SICCFIN - AML/CFT & 20 & 12 \\
\hline
\end{tabular}

Source: Monaco, Department of Finance and the Economy

Notes: DBT $=$ Division of Budget and the Treasury, DEE = Division of Economic Expansion;

CCGP $=$ Supervisory Commission for Portfolio Management,

$\mathrm{FCB}=$ French Banking Commission; DF $=$ Department of Finance and the Economy,

$\mathrm{CSOM}=$ Supervisory Commission for Mutual Funds 


\section{Oversight of companies and trusts service providers}

32. The Minister of State is the competent authority for regulation and supervision of the Monegasque financial services sector. Operational responsibility resides with the Government Counselor for Finance and the Economy (equivalent to Minister of Finance and Economy). This responsibility extends to the regulation and supervision of CSP) with day to day implementation delegated to the DEE.

33. The DEE attaches considerable importance to prevention and its current supervisory emphasis is on licensing. As of April 30, 2002, there were 40 CSPs licensed to operate in Monaco. The licensing requirements are tiered with all applicants required to meet specific minimum standards including a detailed client identification protocol, appropriate education and experience, verification of source of funds, and a police background check.

34. Additional requirements must be met when the legal form selected to hold the license is a Monegasque limited liability company (Société Anonyme Monegasque, SAM).

Conditions for approval unique to the SAM include minimum capitalization of $€ 150,000$, a requirement to retain the services of a notary, appointment of two statutory auditors from an approved list who must prepare an annual statement and a statutory audit report. Law No. 408 requires that accounts be submitted within nine months of every fiscal year. DEE has the power to conduct onsite reviews under Law No. 1.144. It can also nominate a CPA to inspect if accounts are not submitted as required.

35. All individuals and partnerships are licensed for two years renewable upon reapplication. Once licensed, the SAM is exempted from the renewal obligation. However, an annual audit is required, and statutory auditors file a report to the DEE upon discovery of anything not in accord with the authorization. An auditor's adverse filing could result in the referral of the matter by DEE to a standing Monegasque ministerial commission for evaluation and possible withdrawal of license.

36. There are five tests under Law No. 767, any one of which one can result in withdrawal of license: if turnover within a two year period is not significant; if facilities and premises do not comply with those required to conduct its authorized business; deviation from authorized activity; operation of another company without authorization; and bankruptcy.

37. For CSPs that are not SAMS, oversight is currently not as robust as the licensing process. The DEE has power under Law No. 1.144, 1991, to conduct on site reviews. This authority has been sparingly employed. Monegasque regulators recognize their shortfall in obtaining direct and timely information regarding the scope and activities of the 40 licensed CSPs and the foreign companies and trusts they manage. Regulators have proactively moved to remedy this gap.

38. A code of conduct for CSPs, Recommendations Concerning the Management and Administration of Foreign Entities, was developed in August 2001. This laid down the 
requirements and procedures that the CSPs should follow with respect to customer due diligence. All 40 CSPs were required to acknowledge receipt of, and to give the DEE a written commitment to accept, apply, and enforce the Code. A working group comprised of Monegasque regulator/supervisors and members of the financial service industry has produced written guidelines for the conduct of onsite review of all 40 CSPs. The onsite-review program, established by the Code of Conduct, will permit regulators to ensure compliance with the FATF 40+8 Recommendations and to enhance their knowledge of CSPs and their client services. The Code of Conduct is being implemented. The onsite-review program by the DEE for CSPs began in October 2002. ${ }^{10}$ Since the July 12, 2002 amendment to the AML Law, the 40 licensed CSPs are under the same AML/CFT regulatory requirements as banks. SICCFIN began its supervisory program in November 2002. ${ }^{11}$

39. Monegasque regulators estimate that approximately 3,950 offshore companies and 725 trusts are under CSP management, as at April 30, 2002. In global terms, the number of offshore companies and trusts is managed by CSPs is quite small.

\section{Recommendations}

40. In addition to the recent training for SICCFIN staff on the onsite and offsite examination of CSPs, the oversight of CSPs may also be enhanced by expanding training for the examiners who will conduct onsite examination of company service providers to include training programs conducted by regulators in other jurisdictions. ${ }^{12}$

\section{Cooperation and information sharing among supervisors-cross-border and domestically}

41. Information sharing and cooperation among authorities, both domestically and between sovereign states, is a key element in effective supervision of the financial sector. Supervisors must be able to obtain and share information for the purposes of effective supervision of banks, insurance companies, or securities firms that undertake cross-border activity, including establishing branches or subsidiaries in other jurisdictions. Financial

${ }^{10}$ The authorities noted that 18 entities had been examined by end-April, 2003, 14 by the DEE and 4 by SICCFIN; 2 authorizations have been removed as a result. There have also been 6 requests for authorization, 5 of which were refused. A Monegasque CSP professional association is being created.

${ }^{11}$ SICCFIN had visited two entities by end-2002. SICCFIN also organized a seminar for all financial institutions, including CSPs, on the new legislation in December 2002.

12 The initial training of SICCFIN staff was carried out by TRACFIN and other FIUs. In addition, the authorities note, SICCFIN staff recently received training on specific onsite and offsite supervision of CSPs, and SICCFIN is a member of Egmont's working group on training. 
intelligence units and supervisors must also be able to obtain and share information with respect to customer identity and customer transactions in order to effect criminal investigations and to prevent money-laundering and the financing of terrorism.

42. Monaco has recently taken a series of initiatives to improve their cross border cooperation and information sharing. The resulting system would be optimized by providing additional information sharing authority between the mutual funds supervisory commission and other domestic and foreign regulators, and by the specification of formalized arrangements between supervisors.

43. Confidentiality requirements limit the cross-border, cross-sector exchange of information among supervisors and other competent authorities. Specific provisions of law or agreements between countries or authorities are necessary to authorize such exchange of information under conditions that provide appropriate safeguards as to the proper use of the information. ${ }^{13}$.

44. The need for consolidated supervision and monitoring in banking was recognized in SO No. 14.892 of May 2001. The SO confirms the exchange of letters dated April 6, 2001, between Monaco and France agreeing that Monegasque banks can transmit to their parent institutions all information required by the foreign supervisor for consolidated supervision. The SO also allows the FCB to carry out onsite examinations in Monegasque banks on behalf of foreign supervisory authorities. Such examinations, begun in 2001 and conducted in cooperation with the foreign supervisor, cover all information related to the prudential standards of the foreign supervisory authority, in particular, capital adequacy, liquidity, solvency, deposit guaranty, large exposures, and the administrative and accounting organization.

45. Amendments to the portfolio management law in 2001 permitted sharing of information between the portfolio management supervisory commission and foreign securities supervisors, provided that a formal information sharing arrangement is in place. The mutual funds supervisory commission does not have similar authority to share information. Nevertheless, when required for the narrower purpose of consolidated supervision, no formal arrangement is necessary for either supervisory commission to share information. A formal memorandum of understanding was signed with the French

${ }^{13}$ In Monaco, Article 57 of the French banking law of 1984 provides that all directors, officers, and employees of banks are subject to professional secrecy requirements. The Monegasque-French exchange of letters of 1987 (Article 4) made Article 57 of the French banking law applicable in Monaco, with sanctions given by Article 308 of the Monegasque penal code. Similarly, under the Monegasque Law no. 975 of July 12, 1975, on the status of civil servants, all civil servants are bound to professional secrecy with respect to information acquired in the course of their work. A similar provision applies to members of the Supervisory Commission for Portfolio Management (CCGP). 
Commission des Opérations des Bourses (COB) in March 2002, under which the portfolio management supervisory commission can obtain and share any information from regulated entities, provided, it will be used for specified regulatory purposes. Confidentiality of the information is protected under the MOU. This gives the CCGP full authority to obtain and share relevant information with their most important counterpart. There are no formal arrangements in place with other supervisors - however, Monaco has begun negotiations with the securities regulator in Italy and Luxemburg.

46. Information sharing between the FCB and the portfolio management supervisory commission (CCGP) would also benefit from clarification and formalization. Article 13 of Law No. 1.241 of July 3, 2001, allows information sharing with foreign supervisory authorities of portfolio management companies for the purposes of consolidated supervision, but does not refer to portfolio management in banks which is considered covered by the above-mentioned SO No. 14.892. In practice, the Director of Budget and Treasury is a member of the FCB committee on Monegasque banks and is privy to information about the supervision of portfolio management activities of these banks. However, an explicit agreement setting out the precise terms of information sharing between the commissions and the FCB would provide clarity. In addition, although the Department of Finance and Economics staff, who work on regulatory matters day-to-day, are the same for both mutual funds and portfolio management licensees, and the Minister of State is ultimately responsible for decisions in both areas, the two supervisory commissions cannot by law share information between themselves.

47. The mutual funds supervisory commission does not have the authority to share information with foreign securities supervisors. Inspections of mutual funds, their management companies, and custodian banks are undertaken by staff of the French COB on behalf of the CSOM pursuant to a 1992 agreement between the Ministry of State and the COB.

48. In the area of AML/CFT, the Minister of State has the right to provide foreign authorities with information related to transactions that appear to have a link with drug trafficking or organized criminal activity, with terrorism, terrorist acts, or terrorist organizations (Article 31 of the AML Law). This information sharing is subject to reciprocity and the absence of criminal proceeding in the Principality on the basis of the same facts.

49. As has been recognized, the planned signature of an agreement between SICCFIN and the FCB would address the major weakness in SICCFIN's work arising from the limited nature of information sharing arrangements with foreign financial sector supervisors. This would assist SICCFIN in addressing the different criteria required by Basel Core Principle 15, since SICCFIN is the Monegasque bank regulator in AML/CFT.

50. The gateway for the flow of information between the body responsible for the portfolio management activities of banks and SICCFIN, and, more broadly, between local financial sector supervisory agencies, was formalized by the creation of a Coordination Committee by SO No. 15.530 of September 27, 2002. The Committee is chaired by the 
Government Finance and Economic Counselor, and comprises a member of that department (in practice, the person in charge of onsite inspections for portfolio management), the Director of Budget and Treasury (who is a member of the FCB committee on Monegasque banks and of the CCGP), the Director of the DEE, and the Director of SICCFIN. Other qualified persons may be invited to attend meetings of the Committee. The Committee is charged with organizing information exchange and coordination among financial supervisory bodies. 
Figure 1. Flow of Information and Cooperation

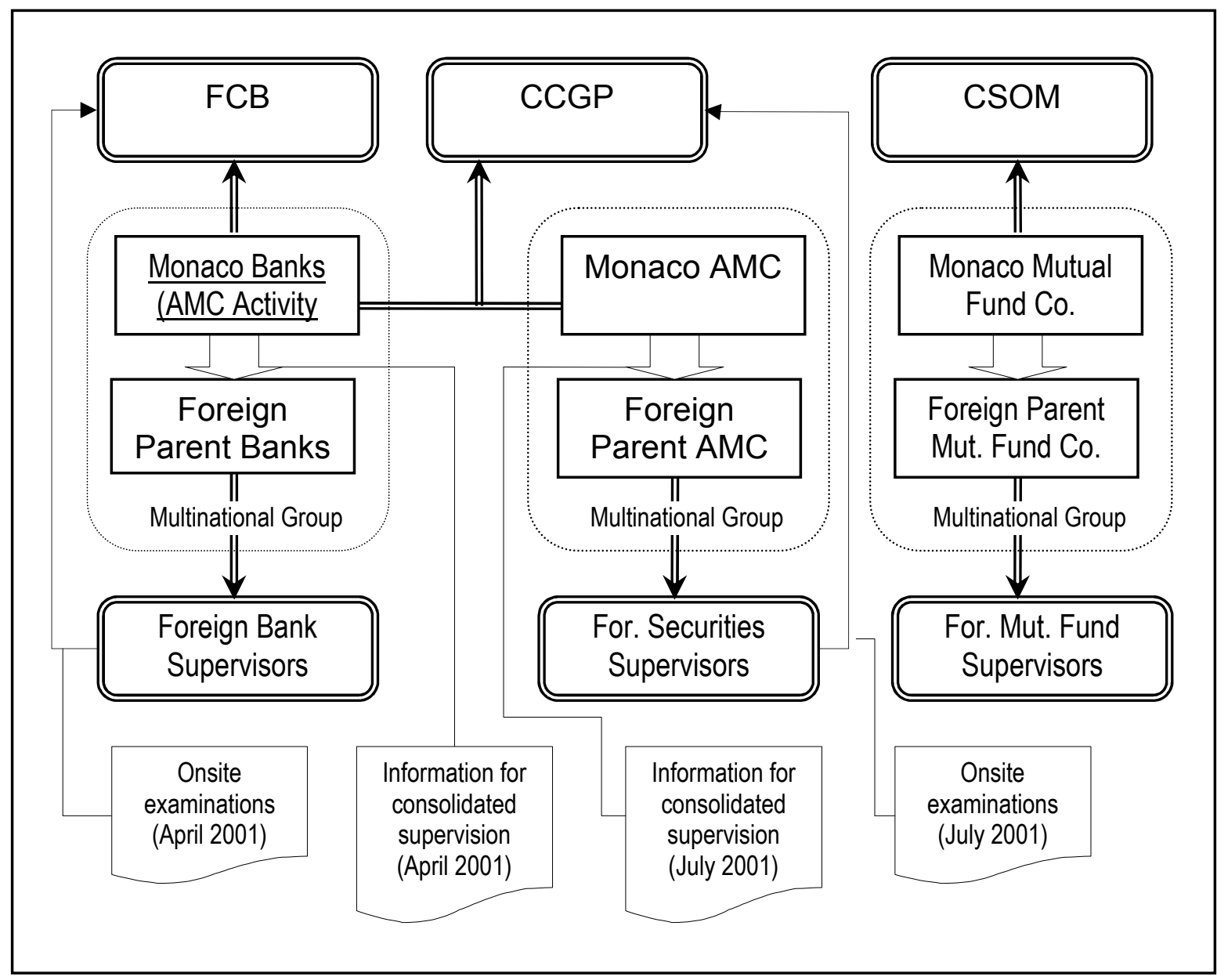

Source: Compiled from information provided by the Monegasque authorities.

Notes: 1. No formal arrangement is necessary for either CCGP or CSOM to share information for consolidated supervision purposes.

2. The chart above illustrates the absence of a formalized gateway between the primary supervisor of asset-management activities, CCGP, and the FCB, and the absence of formal information-sharing arrangements for CSOM. However, the Coordinating Committee established by SO No. 15.530 of September 27, 2002, is given the mandate to organize information exchange among local financial supervisory agencies. (The composition of the Coordination Committee is described in paragraph 50). 


\section{ObSERVANCE OF FinAnCIAL SySTEM STANDARDS AND CODES: SUMMARY ASSESSMENTS}

51. Detailed assessments of compliance with key supervisory and regulatory codes are an important diagnostic tool whereby the supervisory structure and operations are examined and compared to internationally determined standards. The mission undertook a partial review of the Basel Core Principles for Effective Banking Supervision and a full assessment of the implementation of the IOSCO Objectives and Principles of Securities Regulation. The mission also completed a detailed assessment of compliance with anti-money laundering and countering the financing of terrorism provisions across the financial sector under the IMF/World Bank AML/CFT Methodology (April 2002 version), ${ }^{14}$ including both gaming establishments because of their macroeconomic significance, and companies and trust service providers.

\section{A. Basel Core Principles for Effective Banking Supervision}

52. As mentioned above, the Monegasque banking system is subject to French banking law and regulation and the supervision by the FCB. In 2000, France completed a self assessment and received an IMF-led assessment of its compliance with the Basel Core Principles for Effective Banking Supervision as developed by the Basel Committee on Banking Supervision. By extension, the conclusions from these assessments are broadly applicable to the supervision of the Monegasque banking system.

53. However, given the specific responsibility of the Monegasque authorities for $\mathrm{AML} / \mathrm{CFT}$ the supervisory regime in place was assessed vis-à-vis Basel Core Principle (BCP) 1.6 and BCP 15. The findings were as follows:

- $\quad$ BCP 1.6: arrangements for sharing information between supervisors and protecting the confidentiality of such information should be in place. Considerable progress has been made to improve international cooperation among banking supervisors and to increase the ability of Monegasque banks to provide information to their parent banks for the purposes of consolidated supervision. However, the framework should be enhanced by providing for direct formal channels of information exchange between the two supervisors of the Monegasque banks.

- BCP 15: banking supervisors must determine that banks have adequate policies, practices and procedures in place, including strict "know-your-customer" rules that promote high ethical and professional standards in the financial sector and prevent the bank being used, intentionally or unintentionally, by criminal elements. The Monegasque authorities are to be commended for the proactive attitude they have

\footnotetext{
${ }^{14}$ This was superceded in October 2002 by a revised methodology endorsed by FATF, the Fund, and the World Bank
} 
taken lately. However, they will have to continue the ongoing work. The most important weakness relates to the limited nature of possible information sharing with foreign financial sector supervisors. The pending FCB-SICCFIN agreement will have to fill this important gap. SICCFIN has conducted a seminar to inform financial institutions about the requirements of the amended AML Law and has issued recommendations with regard to the freezing of assets. However, it should have a more formalized approach and issue a number of policy guidelines. ${ }^{15}$

54. A comprehensive review of SICCFIN's ongoing work should be organized, preferably no later than the second half of 2003. Given the present AML/CFT workload and the problems that are inevitably linked with every new supervisory activity, this would permit early detection and correction of gaps. The mission has also acknowledged that most banks operating in Monaco are part of large international financial groups and comply with the stricter internal AML requirements of these groups.

\section{B. AML/CFT Assessment Based on Fund/Bank Draft Methodology}

\section{Main findings}

55. Overall, the AML/CFT legal, institutional, and supervisory framework provides a sound basis for the prevention, detection and prosecution of offenses of money laundering and terrorism financing. In particular, the Monegasque authorities are to be commended for taking the necessary steps for Monaco to become a party to the main multilateral conventions on AML/CFT. Monaco has been a party to the Vienna Convention since 1991 and has signed and ratified the Suppression of the Financing of Terrorism Convention and the Palermo Convention. Monaco has recently acceded to the Strasbourg Convention, which entered into force with respect to Monaco in September 2002. In the paragraphs below, the main elements of the AML/CFT framework are summarized, and the recommendations for further action in this regard are set out.

\section{Legal Requirements for financial service providers}

\section{Customer due diligence}

56. The AML Law requires that before opening an account, financial institutions verify the identity of their customer. Financial institutions must also ascertain the identity of their occasional customers who carry out a transaction involving an amount of more than $€ 15,000$

\footnotetext{
${ }^{15}$ The authorities responded that law 1.162, Art. 31, provided SICCFIN with the ability to share information and that SO 15.454, Art. 1, broadens SICCFIN's ability to communicate information to foreign supervisors. By addressing a former major weakness in SICCFIN's role, they consider that this amendment makes SICCFIN compliant with BCP 15, and that as a result, SICCFIN can now cooperate with other FIUs or financial supervisors in all the fields in its scope of competence (see Paragraph 17 of Volume II).
} 
or who rent a safe deposit box. Financial institutions musts also ascertain the identity of persons on whose behalf an account is opened, a safe deposit box is rented, or a transaction is carried out if the person requesting the service appears not to be acting on their own behalf.

\section{Record keeping}

57. Under the AML Law, financial institutions must keep for five years documentary evidence of the identity of their regular and occasional customers and documents related to transactions carried out with all their customers.

\section{Suspicious transaction reporting}

58. Financial institutions and certain other professionals are subject to suspicious transaction reporting requirements. Financial institutions are banks, insurance companies, portfolio management firms, bureaux de change, and company service providers. Financial institutions are also required to report cases where they have refused to undertake a transaction suspected of concerning funds derived from drug trafficking or organized criminal activity. Financial institutions are required to give special attention to transactions above a certain amount (currently $€ 150,000$ ) which are unusual or complex and appear not to have an economic justification. The professions that are subject to suspicious transaction reporting requirements are listed in Sovereign Order No. 14.446 of April 22, 2000, as follows: financial auditors, chartered accountants, accountants and liquidators in bankruptcy, legal and financial advisers, estate agents, cash transporters, retailers in precious stones, precious materials, antiques, works of art, and other valuable objects, company service providers (which are now considered as financial institutions under the amended AML Law). ${ }^{16}$

\section{Internal controls}

59. Under the AML Law, financial institutions have a duty to be vigilant, to introduce internal control procedures, and to provide all appropriate training to the staff concerned. SO No. 11.160 of January 24, 1994, amended by SO No. 15.453 of August 8, 2002, provides additional details. In particular, it specifies the documents required for customer identification, sets a minimum transaction amount of $€ 15,000$, above which financial institutions must verify the identity of occasional customers, and sets at $€ 150,000$ the amount above which financial institutions are required to subject transactions to special scrutiny if

\footnotetext{
${ }^{16}$ Sovereign Order No. 14.446 also included attorneys, except if they have acquired the suspicious information in the course of ensuring the defense of their clients. The status of attorneys' reporting obligations is now unclear since a decision of the Supreme Tribunal of March 6, 2001 struck down the reference to attorneys in the Sovereign Order on the grounds that it was too vaguely worded, but left in place a similar reference to attorneys in the AML Law. It is understood that the matter will be taken up in the context of a forthcoming updating of the Sovereign Order.
} 
the transactions are of a complex and unusual nature and do not appear to have an economic justification. In such cases, financial institutions are required to elicit all possible information regarding the origin and destination of the funds and the purpose and beneficiary of the transaction, and to report their findings to SICCFIN. It requires that financial institutions should state in writing the monitoring procedures whereby they can verify compliance with internal control procedures. Other provisions deal with gaming houses and bureaux de change.

\section{Sanctions}

60. The AML Law provides for appropriate administrative and criminal penalties for failure to comply with the provisions of the Law. Administrative penalties for financial institutions that fail to comply with their reporting, customer due diligence, and record keeping obligations are: a warning, a reprimand, a ban on carrying out certain transactions, and withdrawal of authorization to do business. Criminal penalties for failure to report suspicious transactions or a refusal to undertake a transaction because it appeared suspicious are fines of $€ 9,000$ to $€ 18,000$. Criminal penalties for breach of certain other provisions of the Law, including those regarding record keeping, are fines of $€ 2,250$ to $€ 9,000$.

\section{Integrity standards}

61. In Monaco, all business activities are subject to government authorization under Law 1.144 of July 26, 1991, and such authorizations are issued after an examination of the professional competence and the integrity of the applicant.

62. In addition, specific provisions regarding integrity standards are found in the sectorspecific laws. With respect to banks, for example, the French Law on Banking of 1984 excludes from membership of the board of directors or of a supervisory board of a financial institution, and management positions in a financial institution, persons who have been convicted of a crime or of a number of listed offenses. Specific integrity requirements are also applicable to persons undertaking portfolio management activities in Monaco. In the case of bureaux de change, integrity standards are set out in the AML Law.

\section{Criminalization of $M L$ and FT}

63. Money laundering is criminalized as a serious offense under Articles 218 to $218-3$ of the Penal Code. A separate money laundering offense is provided for with respect to drug offenses in Article 4-3 of Law No. 890 of July 1, 1970. Predicate offenses are listed in Article 218-3 of the Penal Code and consist of forgery, forging or illegally using seals, hallmarks, stamp, and trade marks, misappropriation by persons exercising public authority, extortion, bribery, murder, procuring, kidnapping, and extortion, provided the offence has been committed within the framework of an organized criminal activity. Terrorism financing has not yet been added to the list of predicate offenses. More generally, the list of predicate offenses may need to be reviewed to ensure that includes all serious crimes. 
64. The terrorism financing offenses set out in the International Convention for the Suppression of the Financing of Terrorism have been incorporated in domestic law by SO No. 15.320 of April 8, 2002. The offenses established by the SO include the general financing of terrorism offense set out in the Convention as well as offenses based on eight (of the nine) treaties set out in the Annex to the Convention to which Monaco is a party. In implementing Article 5 of the Convention regarding the criminal liability of legal persons, the SO provides that legal persons (excluding the State, the City, and public agencies), domiciled in Monaco or established under its laws may be held criminally liable for the offenses established under the Convention.

\section{Freezing of transactions and confiscation of proceeds of crime and assets}

65. SICCFIN has the power to freeze a transaction for up to 12 hours on its own initiative. The transaction may be frozen for a longer time by decision of the President of the Tribunal of First Instance (a civil jurisdiction), who can also order the sequestration of the accounts concerned. In addition, under Article 219 of the Penal Code, the criminal court may order the confiscation of the assets and funds of illicit origin. SICCFIN has the power to obtain information from all State agencies. SICCFIN has direct access to the Monaco business registry (including its nonpublic data on partnerships), and can obtain other data on request from other government agencies.

66. The Penal Code provides that the court orders the confiscation of assets and funds ( "biens et capitaux") of illicit origin (i.e., those which are the product of the predicate offenses). Confiscation is without prejudice to the rights of third parties. Except in the case of drug-related laundering, confiscation does not extend to assets which were used in the commission of the predicate offense or which facilitated it. Confiscation of assets of equivalent value is not provided for in the law. SO No. 15.321 of April 8, 2002, requires entities which hold assets of persons and entities linked to the financing of terrorism to freeze them if requested by Ministerial Order. Related Ministerial Orders were issued on April 9, 2002, and in July and October 2002.

\section{Financial information and intelligence: receipt, analysis, and dissemination}

67. The Monegasque FIU, SICCFIN, is established under SO No. 11.246 of April 12, 1994 implementing the AML Law. SICCFIN carries out the following activities: (i) AML supervision of reporting institutions, including onsite inspections; (ii) awarenessraising activities with industry associations of reporting entities, such as the Association Monégasque des Banques; (iii) staff training; (iv) participation in local and international meetings; (vi) receiving and analyzing reports of suspicious transactions; and (vii) cooperation with other FIUs.

68. Under Article 27 of the AML Law, when SICCFIN finds evidence of drug trafficking or organized criminal activity, it forwards a report to the Minister of State. Under Article 28, when the facts may give rise to criminal prosecution, SICCFIN may communicate the same information to the Principal State Prosecutor. It is understood that, in practice, information is 
sent to the Principal State Prosecutor with a copy to the Minister of State. SICCFIN's independence would be enhanced if it were required by law to make its reports directly to the Principal State Prosecutor.

69. SICCFIN is established as a unit of the Department of Finance and Economic Affairs. Its staff are civil servants appointed in the name of the State Minister. The staff of SICCFIN does not enjoy special immunity. However, under the law on the status of civil servants, the State is obligated to defend civil servants against all attacks they may be subjected to in the course of their work, and to compensate them for any loss (Article 4 of Law No. 975 of July 12, 1975 on the status of civil servants).

\section{International cooperation in AML/CFT matters ${ }^{17}$}

70. Monaco is a party to the Vienna Convention, the Suppression of the Financing of Terrorism Convention, the Palermo Convention, and (as of September 2002) the Strasbourg Convention. These conventions contain provisions on mutual legal assistance among the parties in the matters covered by the conventions. In addition, bilateral treaties to which Monaco is a party, including treaties with France, Italy, and Germany provide for mutual legal assistance in criminal matters, often under simplified and accelerated procedures.

71. Extradition is provided for in some of the multilateral conventions mentioned above. In addition, Monaco is a party to some 17 bilateral conventions which provide the legal basis for extradition. In the absence of a treaty, extradition may be requested in certain cases under Law No. 1.222 of December 28, 1999 on extradition.

72. International cooperation in AML/CFT matters is also achieved through the actions of SICCFIN. SICCFIN is a member of the Egmont Group and exchanges information with other members of the Group. It also cooperates with foreign FIUs on specific cases on the basis of MOUs on exchange of information. SICCFIN has entered into seven information exchange MOUs with other FIUs and four more are under discussion. Under the July 2002 amendment to the AML Law, SICCFIN is formally authorized to use its powers of investigation to respond to requests from foreign FIUs.

\section{Licensing and authorizations}

73. As is stated above, in Monaco, all business activities are subject to government authorization under Law No. 1.144 of July 26, 1991, and such authorizations are issued after an examination of the professional competence and the integrity of the applicant. In addition, regulatory authorization is required to undertake most activities in the financial sector.

\footnotetext{
${ }^{17}$ International cooperation in AML/CFT matters includes mutual legal assistance in criminal matters, extradition and exchange of information between FIUs and other competent authorities.
} 


\section{AML/CFT assessment in the prudentially regulated sectors}

74. Overall, the supervisory authorities have the necessary regulations and guidance in place and are providing the necessary oversight of AML/CFT. SICCFIN has the primary responsibility in this regard. In the banking sector, the FCB reviews all aspects of banking activity, including those related to AML/CFT, but SICCFIN has full responsibility for compliance with AML/CFT. In addition, banks' internal audit and the concern to avoid reputation risk, assist in ensuring that good AML practices are followed, including, in particular, good customer due diligence practices. All other financial sectors have customer due diligence guidelines in place, and verification of their implementation is in place or planned, by SICCFIN.

75. SICCFIN has begun to monitor the procedures for suspicious transaction reporting put in place by financial institutions. It has strengthened its supervisory capacity, with increased onsite examinations (which include examination of individual client files) and awareness-raising activities. Several documents related to the FATF requirements have been circulated to the financial sector. SICCFIN has issued two questionnaires to financial institutions, and is using the responses as the basis for onsite supervision.

76. As a result of these activities, the number of suspicious transactions reported has increased, and so has the number of cases forwarded to Principal State Prosecutor. From an average of 45 suspicious transaction reports per year between 1994 and 1999, the number has increased to 210 in 2000 and to 307 in 2001. Similarly, from an average of two files per year transmitted for prosecution from 1994 to 1999, the number has increased to 12 in 2000 and to 21 in 2001 . From 1998 through 2001, some $€ 37$ million had been seized at the request of SICCFIN.

77. To carry out its increased work program and to cope with the increasing number of suspicious transaction reports, SICCFIN's staff resources have been increased from three to eight persons (with a ninth person expected at end-2002), and an intensive training program for SICCFIN staff members has been organized.

78. The number of international letters rogatory (ILR) ${ }^{18}$ executed by Monaco in the last few years illustrates the authorities' determination to cooperate internationally in AML. From 1998 to 2001, the Principal Prosecutor's office received 63 ILR related to money laundering, executed 55 of them, was still processing 8 (in 2002), and did not deny the execution of any. During the same period, Monaco issued 32 ILRs related to money laundering, 11 were executed, 21 are being processed, and none were denied.

\footnotetext{
${ }^{18}$ An international letter rogatory is a formal request from the authorities of one country for assistance from another country in criminal matters.
} 


\section{AML/CFT Assessment of Other Service Providers}

\section{Company service providers}

79. The Direction de l'Expansion Économique (DEE) oversees the 40 licensed Company Service Providers (CSPs). The July 2002 amendment to the AML Law brought AML/CFT supervision of CSPs under the same regulatory framework as financial institutions so that SICCFIN became responsible for supervision of AML/CFT measures. ${ }^{19}$ The authorities would need to ensure that the transition to new arrangements is well planned and executed.

80. With respect to customer identification and due diligence, CSPs are now under the same obligations as other financial institutions under the AML Law. In August 2001 the DEE issued a Code of Conduct addressing the internal control requirements for the CSPs and extending expanded customer due diligence and AML requirements to foreign companies and trusts administered by the CSPs. The Code of Conduct will permit regulators to ensure compliance with the AML Law. Compliance will be ensured by onsite visits. The Code of Conduct also provides additional guidelines and rules regarding third party dealings

81. With respect to record keeping, the July 2002 amendment to the AML Law brought CSPs under the same rules as other financial institutions. Suspicious transaction reports from CSPs are treated by SICCFIN and may lead to criminal prosecution. It may be noted that a large number of CSPs are branches, independent members of global correspondent firms, or affiliates of international CSPs. These CSPs are required to comply with internal record retention protocols that generally reflect the maximum level of requirement within the group.

82. Monegasque regulators acknowledge their weakness in the development of timely information regarding the scope and activities of the 40 licensed CSPs and the foreign companies and trusts they manage. The regulators have proactively moved to remedy this gap. A working group comprised of Monegasque regulator/supervisors and members of the financial service industry has produced written guidelines for the conduct of onsite reviews of all CSPs. This review will start September 1, 2002, and it will be periodically repeated.

\section{Gaming establishments}

83. In view of the importance of the gaming industry in Monaco and the AML risks inherent to this activity, a summary assessment of the gaming industry was carried out. The organizational and administrative arrangements, the customer due diligence, suspicious transaction reporting and cooperation with other authorities were found to be appropriate to the industry in the Monaco context. Customer and transaction record retention policies needed to be formalized, and this was included in the July 12, 2002 amendment to the AML Law.

\footnotetext{
${ }^{19}$ DEE would remain responsible for other oversight, such as licensing, production of accounts, etc.
} 


\section{Recommendations to improve the AML/CFT regime}

84. The 2002 amendments to the AML Law contain a number of significant improvements to the AML/CFT regime, including:

- the inclusion of financing of terrorism offenses in the definition of suspicious transactions to be reported to SICCFIN;

- the inclusion of company service providers in the list of financial institutions subject to the provisions of the AML Law;

- the enactment of formal customer and transactions record-retention requirements for gaming establishments;

- the possibility for SICCFIN to use its powers of investigation to provide information to foreign FIUs.

85. The following additional recommended steps would further enhance the AML/CFT regime:

- the addition of financing of terrorism offenses as predicate offenses for purposes of the definition of money laundering in the Penal Code;

- $\quad$ a decision by SICCFIN to ensure that financial institutions use increased due diligence for higher-risk customers, especially politically exposed persons, their families, and their associates;

- the introduction in the legislation of confiscation of assets of equivalent value and of the confiscation of assets used in the commission of the predicate offense or which facilitated its commission ("instrumentalities");

- $\quad$ taking steps to ensure that the transition to new arrangements for the general oversight and AML/CFT supervision of CSPs is well executed;

- $\quad$ a comprehensive review of SICCFIN's work in the second half of 2003.

\section{IOSCO Objectives and Principles of Securities Regulation}

86. An assessment of the IOSCO Objectives and Principles of Securities Regulation was carried out during the mission - because of the limited nature of permitted securities activity in Monaco; this assessment was confined to relevant Principles. Securities activity in Monaco is strictly confined to mutual fund operation and portfolio management, and the sector appears to be both uniform and concentrated. 


\section{Institutional setting}

87. Authority to regulate securities activity in Monaco is vested in the Minister of State as the administrator of all laws in Monaco. The mutual fund law is contained in Law No. 1.130 of January 8, 1990, relating to mutual funds as amended by Law No. 1.230 of July 6, 2000, and modified by a number of SOs and Ministerial Orders (collectively "the mutual fund law"). The law governing market intermediaries is contained in Law No. 1.194 of July 9, 1997, relating to portfolio management and similar stock market activities, as amended by Law No. 1.241, and two additional SOs (collectively "the portfolio management law"). These laws are largely modeled on French securities law and on the relevant EU directives.

88. A supervisory commission is appointed under each law - these commissions make recommendations on all licensing matters to the Minister of State. The mutual funds supervisory commission is made up of five members plus a president, and the portfolio management supervisory commission has six members plus a president. Currently, the president of both supervisory commissions is the same individual. Three of five members of the mutual fund supervisory commission are staff of the COB (acting in their personal capacity), one an academic and one employed in industry - all members are resident in Paris. The portfolio management supervisory commission is made up of the Director of Budget and Treasury, two staff of the Bank of France (acting in their personal capacities), a staff member of the COB (acting in his personal capacity), a representative of the Monegasque Bankers Association, and a representative of the Monegasque Chartered Accountants Association. Day-to-day responsibilities are undertaken by the Department of Finance and Economics. A delegation agreement is in place whereby staff of the COB carry out inspections of mutual fund companies. Enforcement activities are undertaken by the public prosecutor.

89. Market intermediaries in Monaco are portfolio management firms or banks carrying on portfolio management activity. Restrictions on market intermediary activity are defined in the law-market intermediaries do not execute orders on markets, do not offer margin accounts, and do not engage in proprietary trading, corporate finance, underwriting activities, or any of the activities associated with traditional full-service brokerage firms. Market intermediaries are prohibited from accepting cash or securities from customers and, therefore, do not directly hold client accounts. There are 67 companies in Monaco with a license to carry on portfolio management activities, 43 of which are banks, managing $€ 20$ billion in assets and 24 of which are portfolio management firms, managing $€ 5$ billion.

90. The mutual fund sector is relatively small and concentrated. The total size of the industry is $€ 5.2$ billion including funds that are publicly available and "dedicated" funds which are open only to one investor or institution. A range of funds are offered to the public; however, 66.8 percent of those funds under management are in money-market funds followed by 28.6 percent in diversified funds. Funds may invest in a wide range of products, depending on their approved mandates. The mutual fund business is targeted to Monaco 
investors with accounts too small to justify private portfolio management fees and also to portfolio managers who outsource some asset management. The fund industry is concentrated - with a majority of funds under management located in three banking groups.

\section{Main findings and recommendations}

91. There is no independent regulator in Monaco - responsibility remains vested in the Minister of State; although, two supervisory commissions are in place to provide the Minister with recommendations. The supervisory commissions have the authority to inspect or investigate regulated entities; however, they do not have licensing or sanctioning authority. Nor do the commissions have independent rule-making power. Enforcement of regulations is carried out by the public prosecutor.

92. In the absence of an independent regulator, the use of supervisory commissions brings an important complement of skill and knowledge to the regulatory structure-it is evident that, in practice, the Minister of State defers to the recommendations of these commissions. The merger of the two commissions, whose efforts are currently coordinated through Department of Finance and Economics staff but who cannot work directly together, should be considered. The IOSCO Principles envision a regulator independent from political and commercial considerations with an independent source of funding, the ability to make final binding decisions, and authority to make rules. Increased independence-specifically the conferring of licensing power on the commissions - would bring Monaco closer to implementation of the Principles and would also improve the flexibility and efficiency of the system. Additional attention to transparency and accountability including publication of reasons for withdrawal of licenses, greater reporting on regulatory activity, and the development of conflicts of interest policies would further enhance the quality of the regulatory structure.

93. The recent changes to the law allowing sharing of information have been quickly implemented in the form of an information sharing arrangement with the French securities regulator. This allows the portfolio management supervisory commission to obtain and share information with their most important counterpart. Further development through formal agreements with other supervisors should be encouraged. The authority to share information should be extended to the mutual funds supervisory commission and the two supervisory commissions should have the authority to share information between them. The ability to share information with the FCB regarding the portfolio management activities of banks must also be clarified in the law.

94. Mutual fund regulation includes licensing, internal control, disclosure requirements, and a full program of reporting and inspections. Rules regarding valuation of illiquid securities and related party transactions should be considered. A number of minor issues could be addressed including the Minister of State's authority to put an end to a halt on redemptions; more frequent calculation and publication of net asset valuations for small funds which would improve disclosure to clients and clearer public disclosure of the accounting standards used by the funds in preparing their financial reports. The Monegasque 
authorities have indicated that they would like to have Monegasque mutual funds accepted as EU qualified UCITS (which would grant the funds a "passport" and allow them to be sold throughout the EU) and as a result have kept up with changes to the French law and EU initiatives.

95. Portfolio management firms are subject to comprehensive laws and a full inspection system. It is clear that great improvement has been made in this area since the portfolio management law was passed in 1997. The authorities could consider more frequent reporting of capital as a means of monitoring the industry more closely and should develop a contingency plan for the failure of a portfolio management firm. For the majority of portfolio management which is carried on within banks or at subsidiaries of banks, coordination with the Commission Bancaire would be required. In future, the inspection program should incorporate monitoring of compliance with the new insider trading rules.

96. The question of expansion of permitted securities activity and the structure of regulation in Monaco are connected issues under discussion. There appears to be very little demand within the industry for expanded activity. However, should increased activity be permitted, the regulatory structure would have to address additional complexities - for example, capital rules would have to be expanded to respond to greater risk involved in underwriting, proprietary trading, or extension of credit to clients and a much more robust reporting system, would have to be in place to monitor compliance, or market conduct rules would need to be adopted and a surveillance system put in place if trading on markets was permitted. At the same time, there is an ongoing debate as to whether these two commissions should be merged, and whether the commissions should be imbued with authority to grant and withdraw licenses or to impose sanctions on market participants. The present system is sufficient in the current context; but, it is evident that if permitted activity in the sector did expand, a single and more independent commission would be required.

97. The Monegasque system of securities regulation as it is currently structured is effective - but it must be understood in its own very unique context. Those who wish to carry out securities-related activities in Monaco are already subject to a rigorous and controlled company registration system in addition to separate licensing for securities activity. The government is small and centralized and carefully plans its approach to all commercial activity. An additional layer of control is added through the explicit limits on permitted securities activities. The Monegasque authorities have very deliberately chosen mutual funds and portfolio management as businesses that complement the core industry of private banking in Monaco and have with equal deliberation chosen not to permit activities which would introduce greater risks and would require an expansion of the regulatory structure. 